\title{
Production of an Antiproliferative Furanoheliangolide by Lychnophora ericoides Cell Culture
}

\author{
Pierre Alexandre dos Santos, ${ }^{a}$ Maria Fernanda Castro Amarante, ${ }^{a, b}$ Ana Maria Soares Pereira, ${ }^{b}$ \\ Bianca Bertoni, ${ }^{b}$ Suzelei Castro França, ${ }^{b}$ Cláudia Pessoa,${ }^{c}$ Manoel Odorico de Moraes,${ }^{c}$ \\ Letícia Veras Costa-Lotufo, ${ }^{c}$ Marcio Roberto Pinho Pereira, ${ }^{d}$ and Norberto Peporine Lopes $*, a$ \\ ${ }^{a}$ Faculdade de Ciências Farmacêuticas de Ribeirão Preto, Universidade de São Paulo; Via do Café S/N, CEP 14.040-903, \\ Ribeirão Preto-SP, Brazil: ${ }^{b}$ Departamento de Biotecnologia Vegetal, Universidade de Ribeirão Preto; 14096-380, \\ Ribeirão Preto-SP, Brazil: ${ }^{c}$ Faculdade de Medicina, Universidade Federal do Ceará, Fortaleza; Ceará, 60430-160, Brazil: \\ and ${ }^{d}$ Centro de Ciências da Saúde, Universidade de Fortaleza; Ceará, 60430-160, Brazil.
}

Received May 17, 2004; accepted September 8, 2004

This work reports for the first time the production a furanoheliangolide (goyazensolide) by plant cell culture. Monitoring of the goyazensolide metabolism revealed that the maximum production occurred during the lag phase of the Lychnophora ericoides callus culture. The antiproliferative activity of obtained goyazensolide was evaluated against seven cancer cell lines using MTT assay. The results revealed a potent cytotoxic activity for the furaheliangolide with $\mathrm{IC}_{50}$ values in the range of $0.06 \mu \mathrm{g} / \mathrm{ml}$ for $\mathrm{CEM}$ leukemia cells to $0.75 \mu \mathrm{g} / \mathrm{ml}$ for $\mathrm{B} 16$ melanome cells.

Key words Lychnophora ericoides; plant cell culture; antiproliferative effect; sesquiterpene lactone; goyazensolide

Lychnophora ericoides MART. is a Brazilian Asteraceae from the central "cerrado" region of Brazil. ${ }^{1)}$ This species is popularly known as "falsa arnica" or "arnica da serra" and it is used in folk medicine as an analgesic or as an anti-inflammatory agent. ${ }^{1)}$ Previous phytochemical investigations carried out on various parts of the plant (including the roots, aerial parts, glandular extracts from the leaves) have described the occurrence of steroids, triterpenes, flavonoids, furanoheliangolides and lignans. ${ }^{2-4)}$ The lignan cubebin, isolated from the roots showed in vivo analgesic activity, but no significant anti-inflammatory or antipyretic effects. ${ }^{3)}$ On the other hand, furanoheliangolides may modulate the antiinflammatory process by in vitro inhibition of the transcription factor NF-k $\beta$ selectively alkylating its p65 subunit. ${ }^{5)}$ The most potent furanoheliangolide normally belongs to the goyazensolide class of compounds. The intramolecular stereospecific Michael addition of this moiety produces the eremantholide, normally resulting in the loss of anti-inflammatory activity. ${ }^{5}$ ) Centratherin and goyazensolide (Fig. 1) isolated from glandular extracts of the plants are the most potent anti-inflammatory members (by in vitro NF-k $\beta$ inhibition) of this class of molecules. ${ }^{4,5)} \mathrm{NF}-\mathrm{k} \beta$ inhibition (by the selective alkylation) could be related to oncogenesis, triggering cell proliferation and inhibiting apoptosis, which also make this transcriptional factor an interesting target in anticancer therapy. ${ }^{6}$

Commercial exploitation of "arnica da serra" within the native areas of Brazil has resulted in a devastating decline of the plant populations. Now the Brazilian Botanical Society has included this plant species in the list of Brazilian plants that are likely to become extinct. ${ }^{7)}$ Recently, germination and propagation experiments showed a low development, by a complex symbiosis system, between $L$. ericoides plantlets and some endemic genus of micorrize. ${ }^{8)}$ An alternative to preserve the population of "arnica da serra" for further chemical and biological studies is an in vitro culture development. In addition, the goyazensolide moiety exhibit a very complex and characteristic cycles made by plant enzymes and are very hard to obtain by synthesis. ${ }^{9)}$ Based on this previous information, the aims of the present work were to obtain a callus culture of $L$. ericoides, to study the production of the previously isolated compounds and also to evaluate the antiproliferative effects toward tumor cell lines.

\section{Experimental}

General Experimental Procedures All solvents were redistilled. Merck silica gel 60 (230 - 240 mesh) and silica gel $60 \mathrm{GF}_{254}$, were used for vacuum flash chromatography and thin layer chromatography. Gas chromatography (Hewlett Packard Series II) was conducted using an HP-1 column, detector temperature of $300^{\circ} \mathrm{C}$, injector temperature of $250^{\circ} \mathrm{C}$ and Hydrogen as the carrier gas. HPLC (Shimadzu LC-6A) was performed using a UV detector $(266 \mathrm{~nm})$ and a Shim-Pack ODS $(5 \mu \mathrm{m})$ column. IR spectra were obtained on a Nicole Protégé 460 . The ${ }^{1} \mathrm{H}-\mathrm{NMR}$ spectra were recorded at $300 \mathrm{MHz}$ and the ${ }^{13} \mathrm{C}-\mathrm{NMR}$ spectra at $75 \mathrm{MHz}$ (Bruker DPX-300). ESIMS analyses were performed at low-resolution on a Quattro-LC instrument (Micromass, Manchester, U.K.).

Plant Material Achenes of $L$. ericoides were collected from Ibiraci, Minas Gerais, Brazil in February 1999, and were identified by João Semir, University of Campinas, Brazil, where a voucher specimen is deposited (NPL-122).

Establishment and Maintenance of Callus Culture Achenes surface were disinfected with $1 \%$ benomil $(\mathrm{w} / \mathrm{v})$ for $24 \mathrm{~h}$ under continuous agitation and then immersed in $70 \%$ ethanol $(\mathrm{v} / \mathrm{v})$ for $1 \mathrm{~min}$. They were then kept in $0.5 \%$ calcium hypochlorite $(\mathrm{w} / \mathrm{v})$ for $30 \mathrm{~min}$ and inoculated. The MS basal medium was supplemented with $3 \%$ sucrose $(\mathrm{w} / \mathrm{v})$. The medium was solidified with $0.2 \%$ Phytagel and $\mathrm{pH}$ adjusted to 6.0 before autoclaving at $121{ }^{\circ} \mathrm{C}$ for $20 \mathrm{~min}$. The obtained plantlets were maintained for three months on MS medium with $3 \%$ sucrose $(\mathrm{w} / \mathrm{v}), \alpha$-naphthaleneacetic acid $(2.0 \mathrm{mg} / \mathrm{l})$ and 6-benzylaminopurine $(4.0 \mathrm{mg} / \mathrm{l})$. The plantlets were transferred to fresh medium under sterile conditions in intervals of $30 \mathrm{~d}$. Leaf explants from plantlets were placed on MS agar medium containing 3\% of sucrose, and combination 2,4-dichlorophenoxyacetic acid (2,4-D), 6-benzylaminopurine (BA), $\alpha$-naphthaleneacetic acid (NAA), indolacetic acid (IAA), zeatin and citocin. The matrix combination was done using concentrations between 0.1 to $1.0 \mathrm{mg} / 1$ to the followed pairs: 2,4-D and BA, 2,4-D and NAA, 2,4-D and IAA, 2,4-D and zeatin, 2,4-D and citocin, BA and NAA, BA and IAA, NAA and IAA, to induce callus formation. To define the influence of 2,4-D concentration a second experiment was performed using 2.0 and $3.0 \mathrm{mg} / \mathrm{l}$. The callus that exhibited the presence of furanoheliangolide in IR analysis were maintained by subculturing every $15 \mathrm{~d}$ to a fresh medium over 6 months at 
$25^{\circ} \mathrm{C}$ under $16 \mathrm{~h}$ photoperiod. Callus growth was determined by measuring fresh weight and expressed as a percentage of total growth.

Extraction and Isolation The lyophilized calli $(38.83 \mathrm{~g})$ of $L$. ericoides were powdered and extracted with $\mathrm{MeOH}$ at room temperature and produced $4.0 \mathrm{~g}$ of crude extract. The extract was submitted to vacuum-liquid chromatography, eluted with $\mathrm{CH}_{2} \mathrm{Cl}_{2}$ and $\mathrm{MeOH}$ to yield $3.2 \mathrm{~g}$ and $0.25 \mathrm{~g}$ of material respectively. The $\mathrm{CH}_{2} \mathrm{Cl}_{2}$ fraction was analyzed by $\mathrm{IR},{ }^{1} \mathrm{H}$ - and ${ }^{13} \mathrm{C}$-NMR, that indicate the presence of a mixture of stigmasterol, campesterol and $\beta$-sitosterol as the major compounds. To confirm the presence of the steroides the CG analysis (co-injection) were performed as previous described in the quantification of steroides in guaco callus using Supelco standars (Bellefonte, PA, campesterol lot: LA 89298; $\beta$-sitosterol lot: LA 81076 and stigmasterol lot: LA 89840).

The methanolic fraction was submitted to preparative HPLC (ODSShimadzu, $5.0 \times 250 \mathrm{~mm}$ column, $\mathrm{MeOH}-\mathrm{H}_{2} \mathrm{O} 50: 50, \lambda=280 \mathrm{~nm}$, flow $8 \mathrm{ml} / \mathrm{min}$ ) producing the sesquiterpene lactone goyazensolide $(1.5 \mathrm{mg})$. Goyazensolide was a white crystal. IR $v_{\max }\left(\right.$ film) $\mathrm{cm}^{-1}: 3400-3100(\mathrm{OH})$ $1771(\mathrm{C}=\mathrm{O}$, lactone $), 1705(\mathrm{C}=\mathrm{O}$, ester $), 1654(\mathrm{C}=\mathrm{C}), 1588(\mathrm{C}=\mathrm{C}), 1300$ $(\mathrm{C}-\mathrm{O}), 1100(\mathrm{C}-\mathrm{O}) .{ }^{1} \mathrm{H}-\mathrm{NMR}\left(300 \mathrm{MHz}, \mathrm{CDCl}_{3}\right) 5.80(1 \mathrm{H}, \mathrm{s}, \mathrm{H}-2), 6.28$ $(1 \mathrm{H}, \mathrm{dt}, J=1.6,3.0 \mathrm{~Hz}, \mathrm{H}-5), 5.34(1 \mathrm{H}, \mathrm{m}, \mathrm{H}-6), 3.79$ (1H, m, H-7), 4.55 $(1 \mathrm{H}, \mathrm{dt}, J=2.5,1.6 \mathrm{~Hz}, \mathrm{H}-8), 2.50(1 \mathrm{H}, \mathrm{dd}, J=1.6,13.8 \mathrm{~Hz}, \mathrm{H}-9 \alpha), 2.32$ $(1 \mathrm{H}, \mathrm{dd}, J=2.1,13.8 \mathrm{~Hz}, \mathrm{H}-9 \beta), 6.23(1 \mathrm{H}, \mathrm{d}, J=3.1 \mathrm{~Hz}, \mathrm{H}-13 \mathrm{a}), 5.47(1 \mathrm{H}, \mathrm{d}$, $J=2.5 \mathrm{~Hz}, \mathrm{H}-13 \mathrm{~b}), 1.54$ (3H, s, H-14), 4.40 (3H, dd, $J=1.7,2.9 \mathrm{~Hz}, \mathrm{H}-15)$, $6.01\left(1 \mathrm{H}, \mathrm{dq}, J=1.0,2.0 \mathrm{~Hz}, \mathrm{H}-3^{\prime} \mathrm{a}\right), 5.55\left(1 \mathrm{H}, \mathrm{dq}, J=1.5,2.0 \mathrm{~Hz}, \mathrm{H}-33^{\prime} \mathrm{b}\right)$, $1.83\left(3 \mathrm{H}, \mathrm{t}, J=1.5 \mathrm{~Hz}, \mathrm{H}-4^{\prime}\right)$. ESI-MS $[\mathrm{M}+\mathrm{H}]^{+} 361$ and $[\mathrm{M}+\mathrm{Na}]^{+} 383$.

Steroid Quantification by Gas Chromatography The friedelanol internal standard (I.S.) was added $(9 \mu \mathrm{g})$ to the lyophilized cells $(20 \mathrm{mg})$ following extraction with $5 \mathrm{ml}$ of $\mathrm{CH}_{2} \mathrm{Cl}_{2}$ (three times). The solvent was evaporated to dryness and the extract dissolved in $\mathrm{CH}_{2} \mathrm{Cl}_{2}(125 \mu \mathrm{l})$. Gas chromatography was performed on a Hewlett Packard (Wilmington, DE, U.S.A.) Series II GC using an HP-1 column $(30 \mathrm{~m} \times 0.25 \mathrm{~mm}, 0.25 \mu \mathrm{m})$, FID detector at $300^{\circ} \mathrm{C}$, manual injector at $250^{\circ} \mathrm{C}$ with hydrogen as the carrier gas (linear velocity $39 \mathrm{~cm} / \mathrm{s}$ ). Column oven temperature conditions were as follows: initial temperature $250^{\circ} \mathrm{C}$ was held for $12 \mathrm{~min}$ then increased by $6^{\circ} \mathrm{C} / \mathrm{min}$ to $280^{\circ} \mathrm{C}$, where it was held constant for $15 \mathrm{~min}$. Two microliters of the samples were injected on the column, at a split rate of $1: 60$. Supelco standards (Bellefonte, PA, campesterol lot: LA 89298; $\beta$-sitosterol lot: LA 81076 and stigmasterol lot: LA 89840) were applied to prepare the Calibration graphs. All the analysis were performed in triplicate and the the means were used to express the production.

Goyazensolide Quantification by HPLC To lyophilized cells $(50 \mathrm{mg})$ were added $9 \mu \mathrm{g}$ of internal standard (16 $\alpha$ - $\left(1^{\prime}, 2^{\prime}\right.$-dihidroxy-1'-methylpropyl)-eremantholide from our sesquiterpene bank of compounds, FCFRPUSP) following extraction with $5 \mathrm{ml}$ of $\mathrm{MeOH}$ (three times). The solvent was evaporated to dryness and the extract dissolved in $150 \mu \mathrm{l}$ of the mobile phase. Each fraction was centrifuged at $2500 \boldsymbol{g}$ for $5 \mathrm{~min}$ and $10 \mu \mathrm{l}$ was injected into the chromatographic system. The HPLC analyses were carried out at $22^{\circ} \mathrm{C}$ on a Shim-Pack ODS column $(4.5 \times 250 \mathrm{~mm}, 5 \mu \mathrm{m}$ particle size). The mobile phase for the analysis consisted of $\mathrm{MeOH}-\mathrm{H}_{2} \mathrm{O}$ gradient ( $30 \% \mathrm{MeOH}$ to $60 \% \mathrm{MeOH}$ in $15 \mathrm{~min}, 60 \% \mathrm{MeOH}$ by $25 \mathrm{~min}$, to $100 \%$ $\mathrm{MeOH}$ in $5 \mathrm{~min}$ ) at a flow rate of $1 \mathrm{ml} / \mathrm{min}$. All the analysis were performed in triplicate and the means were used to express the production.

Determination of Antiproliferative Activity The activity of the goyazensolide on cellular growth was evaluated against seven tumor cell lines (National Cancer Institute, Bethesda, MD, U.S.A.): B-16 (murine skin), HCT-8 (human colon), MCF-7 (human breast), SF-268 (human nervous system), PC-3 (human prostate), CEM and HL-60 (human leukemias). All cell lines were maintained in RPMI 1640 supplemented with $10 \%$ fetal bovine serum, $2 \mathrm{~mm}$ glutamine, $100 \mathrm{U} / \mathrm{ml}$ penicillin, $100 \mu \mathrm{g} / \mathrm{ml}$ streptomycin at $37^{\circ} \mathrm{C}$ with $5 \% \mathrm{CO}_{2}$. Tumor cell growth was quantified by the ability of living cells to reduce the yellow dye 3-(4,5-dimethyl-2-thiazolyl)-2,5diphenyl-2 $H$-tetrazolium bromide (MTT) to a purple formazan product. ${ }^{10)}$ For experiments, cells were plated in 96-well plates $\left(10^{5}\right.$ cells/well for adherent cells or $3 \times 10^{5}$ cells/well for suspended cells in $100 \mu \mathrm{l}$ of medium). After $24 \mathrm{~h}$, goyazensolide $(0.04$ to $2.5 \mu \mathrm{g} / \mathrm{ml})$ dissolved in DMSO $(1 \%)$ was added to each well and incubated for $3 \mathrm{~d}(72 \mathrm{~h})$. Control groups received the same amount of DMSO. Doxorubicin and etoposide were used as positive controls. Thereafter, the plates were centrifuged and then, the medium was replaced by fresh medium $(200 \mu \mathrm{l})$ containing $0.5 \mathrm{mg} / \mathrm{ml} \mathrm{MTT}$. Three hours later, the MTT formazan product was dissolved in $150 \mu \mathrm{l} \mathrm{DMSO}$, and absorbance was measured using a multiplate reader (Spectra Count, Packard, Ontario, Canada). Drug effect was quantified as the percentage of control absorbance of reduced dye at $550 \mathrm{~nm}$.

\section{Results and Discussion}

Initial experiments with explants from mature leaves of $L$. ericoides showed no cellular proliferation and a high level of contamination by microorganisms. Calli were induced from explants from plantlet leaves obtained by in vitro achenes germination. The influence of auxins, NAA, IAA, BA and 2,4-D and their combination with zeatin and cinetin were evalutated. The results showed that it was possible to induce cellular proliferation and callus formation by adding 2,4-D, between 0.1 to $1 \mathrm{mg} / \mathrm{l}$ to the medium. Combination of 2,4-D $(1 \mathrm{mg} / \mathrm{l})$ and BA $(0.1 \mathrm{mg} / \mathrm{l})$ also result in callus formation. We also observed that higher doses of 2,4-D $(2.0,3.0 \mathrm{mg} / \mathrm{l})$ are less effective in inducing callus in this tissue. The NAA, IAA and cinetin and zeatin showed no influence in the callus formation at the assayed doses $(0.1$ to $1.0 \mathrm{mg} / \mathrm{l})$. After $30 \mathrm{~d}$ of culture, 2,4-D plus BAP showed the best growth for production of friable calli and it was the only culture media that exibit the typical absortion from furanheliangolide in IR spectra. These lines were subcultured to a fresh medium [MS supplied with 2,4-D $(1 \mathrm{mg} / \mathrm{l})$ and BA $(0.1 \mathrm{mg} / \mathrm{l})]$ each $15 \mathrm{~d}$ over 6 months. After this time the yield of growth was determined by fresh weight. No significant growth of the calli was observed until the 6th day and then exponential growth was observed until the 24th day (2.5 ratio of growth). Part of the calli were powdered and extracted with $\mathrm{MeOH}$. The IR spectrum of the dried methanolic extract showed again the absorptions at $1771 \mathrm{~cm}^{-1}$ ( $\gamma$-lactone), 1705 and $1588 \mathrm{~cm}^{-1}$ (furanone), which are indicative of a furanoheliangolide., ${ }^{2,4)}$ Supported by the IR spectrum the phytochemical investigation was developed to look for the furanoheliangolides. The extract was partitioned and the apolar fraction afforded the steroids stigmasterol, campesterol and $\beta$-sitosterol. The compound structures were determined by spectroscopy evidence and by GC analysis with co-injection with Supelco standards (see Experimental). After the purification steps the polar fraction yielded a white crystal that was analysed by IR, ${ }^{1} \mathrm{H}-\mathrm{NMR}$ and ESI-MS. The IR spectra showed the same characterist signals (for furanoheliangolides) as previously observed in the crude extract. The ESI-MS showed the presence of the $[\mathrm{M}+\mathrm{H}]^{+} 361$ and $[\mathrm{M}+\mathrm{Na}]^{+} 383$ that indicate the presence of the anti-inflammatory sesquiterpene lactone goyazensolide (Fig. 1), previously isolated from L. ericoides glandular extract. ${ }^{4}$ Finally the analysis of the ${ }^{1} \mathrm{H}-\mathrm{NMR}$ spectrum (see Experimental) confirmed the goyazensolide structure by comparison with the literature data.

For quantification of the isolated steroids during the calli growth, a GC method was developed using friedelanol as an internal standard (I.S.). The results demonstrated a linear relationship between the analyts peak rate areas and concentrations. The linearity of the data was demonstrated by the regression coefficient obtained $(r>0.999$, Table 1). The quantification of the goyazensolide was performed using a method developed for HPLC, using $16 \alpha-\left(1^{\prime}, 2^{\prime}\right.$-dihidroxy-1'-

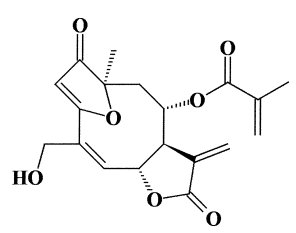

Fig. 1. Structure of the Goyasenzolide 
Table 1. Calibration Graphs for Sesquiterpene Lactone Goyazensolide Analysis by HPLC and Sterols Analysis by GC

\begin{tabular}{llcc}
\hline \hline \multicolumn{1}{c}{ Analyte } & Regression line & $r$ & $\begin{array}{c}\text { Concentration } \\
(\mu \mathrm{g} / \mathrm{ml})\end{array}$ \\
\hline Goyazensolide & $Y=3.32925+1.09324 x$ & 0.9999 & $3.75-600$ \\
Stigmasterol & $Y=0.00384+0.00875 x$ & 0.9966 & $3.125-50$ \\
$\beta$-Sitosterol & $Y=0.00412+0.01113 x$ & 0.9982 & $3.125-50$ \\
Campesterol & $Y=0.0008575+0.01173 x$ & 0.9987 & $3.125-50$ \\
\hline
\end{tabular}

$Y=$ peak area of analyte/peak area internal standard (for steroid analysis was fridelanol for goyazensolide was $16 \alpha-\left(1^{\prime}, 2^{\prime}\right.$-dihidroxy-1'-methylpropil)-eremantholide), $x=$ mass injected, $r=$ correlation coeficient. Concentration express the range of linearity.

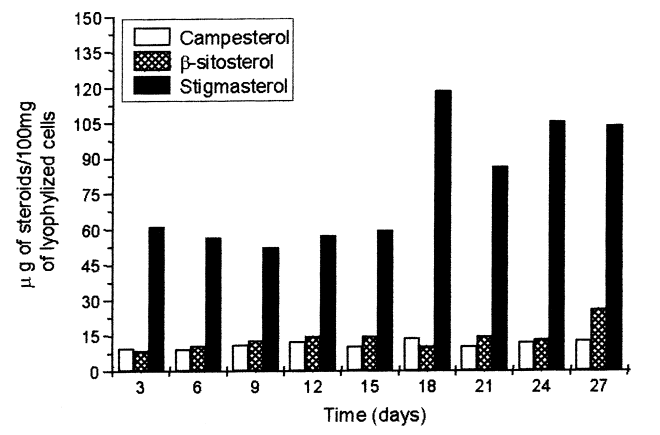

Fig. 2. Production of Steroids by Lychnophora ericoides Callus Culture The reproducibilty was between 1 and $2 \%$ for the 3 repetitions.

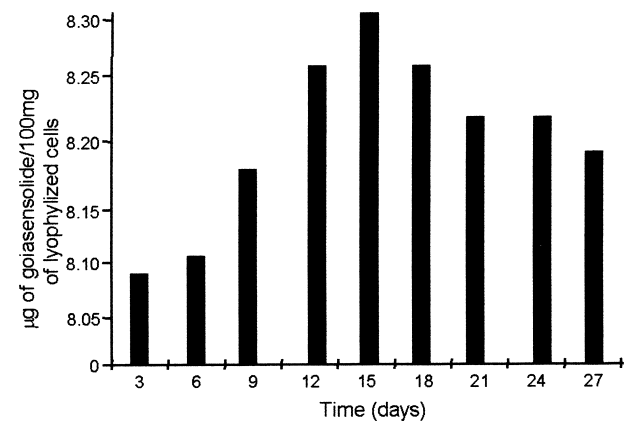

Fig. 3. Production of Goyazensolide by Lychnophora ericoides Callus Culture

The reproducibilty was between 1 and $2 \%$ for the 3 repetitions.

methylpropyl)-eremantholide as I.S. The results obtained for goyazensolide also showed strong linearity with a good regression coefficient (Table 1).

The major steroid production started in the lag phase with the maximum production occurring during the 18th day and then, their concentrations remained constant (Fig. 2). As expected, the production of the sesquiterpene lactone (Fig. 3) was observed to be lower than the steroids (Fig. 2). Biosynthesis of goyazensolide started at the beginning of the lag phase with the maximum during the 15th day and started to decrease as shown in Fig. 2. The decrease in the goyazensolide accumulation could be related to several chemical possibilities including the cyclisation to eremantholide moiety.

To evaluate the anticancer potential of goyazensolide, seven tumor cell lines were treated with increasing concentrations of the isolated compound $(0.04$ to $2.5 \mu \mathrm{g} / \mathrm{ml})$ for $72 \mathrm{~h}$. The goyazensolide activity was further compared to doxorubicin and etoposide. As shown in Table 2, goyazensolide was more active than etoposide on human adherent
Table 2. Antiproliferative Effects of Goyasenzolide Obtained from Callus Culture of Lychnophora ericoides on Tumor Cell Lines

\begin{tabular}{lccc}
\hline \hline Cell line & $\begin{array}{c}\text { Goyazensolide } \\
\mathrm{IC}_{50} \mu \mathrm{g} / \mathrm{ml}(\mu \mathrm{M})\end{array}$ & $\begin{array}{c}\text { Etoposide } \\
\mathrm{IC}_{50} \mu \mathrm{g} / \mathrm{ml}(\mu \mathrm{M})\end{array}$ & $\begin{array}{c}\text { Doxorubicin } \\
\mathrm{IC}_{50} \mu \mathrm{g} / \mathrm{ml}(\mu \mathrm{M})\end{array}$ \\
\hline HL-60 & $0.076(0.211)$ & $0.007(0.012)$ & $0.016(0.028)$ \\
& $0.005-0.113$ & $0.005-0.009$ & $0.013-0.019$ \\
CEM & $0.060(0.167)$ & $0.030(0.051)$ & $0.018(0.031)$ \\
& $0.052-0.069$ & $0.024-0.037$ & $0.015-0.022$ \\
MCF-7 & $0.421(1.169)$ & $>5.886(10.0)$ & $0.203(0.350)$ \\
& $0.341-0.520$ & & $0.170-0.241$ \\
HCT-8 & $0.106(0.294)$ & $0.112(0.190)$ & $0.037(0.064)$ \\
& $0.099-0.113$ & $0.070-0.181$ & $0.028-0.049$ \\
B16 & $0.748(2.078)$ & $0.109(0.185)$ & $0.030(0.052)$ \\
& $0.638-0.876$ & $0.080-0.149$ & $0.024-0.036$ \\
PC3 & $0.602(1.672)$ & $>5.886(10.0)$ & $0.240(0.414)$ \\
& $0.556-0.652$ & & $0.213-0.269$ \\
SF-268 & $0.699(1.942)$ & $2.530(4.298)$ & $0.114(0.196)$ \\
& $0.642-0.761$ & $1.547-4.138$ & $0.112-0.184$ \\
\end{tabular}

Data are presented as $\mathrm{IC}_{50}$ values and $95 \%$ confidence interval obtained by non-linear regression for leukemia (HL-60 and CEM), breast (MCF-7), colon (HCT-8), murine skin (B-16), prostate (PC3) and Central Nervous System (SF-268) cancer cells from three independent experiments. Doxorubicin and etoposide were used as positive controls.

cells, but was weaker than doxorubicin. The $\mathrm{IC}_{50}$ ratio (goyazensolide/doxorubicin) varies from 2.0 on MCF-7 cells to 6.1 on SF-268 cells.

Sesquiterpene lactones form one of the largest group of plant-derived antitumor compounds. ${ }^{11,12)}$ However, this is the first report on the antiproliferative activity of furanoheliangolides possessing the goyazensolide moiety. This functional group seems to add to the activity, since the reported compounds showed cytotoxicity compared two clinically used chemotherapic drugs.

From these results, it is concluded that it is possible to obtain a sesquiterpene lactone from a callus culture of Lychnophora ericoides. This study demonstrates a successful alternative to help preserve the population of this endemic species. Furthermore, furanoheliangolides belonging to the goyazensolide class may be a promising group of antitumor compounds.

Acknowledgements The authors are grateful to FAPESP (Fundação de Amparo a Pesquisa do Estado de São Paulo), to CNPq (Conselho Nacional de Desenvolvimento Científico e Tecnológico) and CAPES (Coordenação Aperfeiçoamneto de Pessoal de Nível Superior) for financial supports. The authors also thank Dr. Paul Gates (School of Chemistry, Bristol University) for the English language revision.

\section{References}

1) Cerqueira M. B. S., Souza J. T., Júnior R. A., Peixoto A. B. F., Ciênc. Cult., 39, 551-553 (1987).

2) Borella J. C., Lopes J. L. C., Vichnewski W., Cunha W. R., Herz W., Biochem. Syst. Ecol., 26, 671-676 (1998).

3) Borsato M. L. C., Grael C. F. F., Souza G. E. P., Lopes N. P., Phytochemistry, 55, 809-813 (2000).

4) Sakamoto H. T., Flausino D., Castellano E. E., Stark C. B. W., Gates P., Lopes N. P., J. Nat. Prod., 66, 693-695 (2003).

5) Rüngeler P., Castro V., Mora G., Gören N., Vichnewiski W., Pahl H. L., Merfort I., Schmidt T., J. Bioorg. Med. Chem., 7, 2343-2352 (1999).

6) Lin A., Karin M., Semin. Cancer Biol., 13, 107-114 (2003).

7) Sociedade Botânica do Brasil, "Centuria Plantarum Brasiliensium Extintionis Miniata," Sociedade Botânica do Brasil, 1992, p. 175.

8) Lopes N. P., Pesquisa FAPESP, 64, 42- 44 (2001).

9) Fischer N. H., Recent Adv. Phytochem., 24, 161-167 (1991).

10) Mosmann T., J. Immunol. Meth., 16, 55-63 (1983).

11) Picman A. K., Biochem. System. Ecol., 14, 255-281 (1986).

12) Konish T., Shimada Y., Nagao T., Okabe H., Konoshima T., Biol. Pharm. Bull., 25, 1370-1372 (2002). 